\title{
EVALUASI KINERJA SISTEM INFORMASI AKUNTANSI ACCURATE ACCOUNTING ENTERPRISE MENGGUNAKAN METODE PIECES
}

\author{
Annisa Eka Pratiwi ${ }^{1}$, Sari Susanti ${ }^{2}$ \\ 1 Universitas Adhirajasa Reswara Sanjaya \\ e-mail: annisaekapratiwi1@gmail.com \\ ${ }^{2}$ Universitas Adhirajasa Reswara Sanjaya \\ e-mail: sarisusanti@ars.ac.id
}

\begin{abstract}
Abstrak
Sistem informasi akuntansi merupakan rangkaian kegiatan memproses transaksi atau suatu kejadian menjadi suatu bentuk catatan tertulis yang tertuang dalam jurnal akuntansi hingga menghasilkan laporan keuangan. Salah satu program yang dirancang untuk memenuhi kebutuhan perusahaan dalam hal pencatatan akuntansi dan keuangan yang sudah mengikuti standar PSAK di Indonesia adalah Accurate Accounting Enterprise. Penelitian ini dilakukan untuk mengevaluasi faktor-faktor yang mempengaruhi keberhasilan kinerja sistem informasi akuntansi Accurate Accounting Enterprise menggunakan metode PIECES dengan enam variabel bebas dan satu variabel terikat yaitu performance, information and data, economics, control and security, efficiency, service. Penelitian ini dilakukan terhadap 45 responden yang menggunakan dan menerima manfaat Accurate Accounting Enterprise pada PT. Gunung Amal Solution International. Metode pengumpulan data menggunakan observasi, wawancara, kuesioner, dan studi pustaka. Metode pengolahan data yang digunakan adalah regresi linear berganda. Dari hasil penelitian tersebut diperoleh hasil analisis bahwa variabel performance, information and data, economics, control and security, efficiency, service memiliki nilai korelasi sebesar 0,631 terhadap keberhasilan kinerja sistem, artinya variabel independen dan dependen dalam penelitian ini memiliki hubungan yang kuat, nilai $F$ hitung sebesar 13,353 nilai $R$ Square (R2) sebesar $63 \%$ sedangkan sisanya dipengaruhi faktor-faktor lain. Dari pengolahan data tersebut didapatkan hasil bahwa secara simultan, variabel performance, information and data, economics, control and security, efficiency, service berpengaruh signifikan terhadap keberhasilan kinerja sistem. Secara parsial, hanya variabel information and data yang memiliki pengaruh positif signifikan terhadap keberhasilan kinerja sistem, sedangkan performance, economics, control and security, efficiency, service memiliki pengaruh negatif signifikan terhadap keberhasilan kinerja sistem informasi akuntansi Accurate Accounting Enterprise.
\end{abstract}

Kata Kunci: Sistem Informasi Akuntansi, Evaluasi Keberhasilan Kinerja, Accurate Accounting Enterprise, PIECES.

\begin{abstract}
The accounting information system is a series of processing transactions or events into a form of written records contained in the accounting journal to produce financial statements. One program that is designed to meet the needs of companies in terms of accounting and finance that has followed the financial accounting standard principles in Indonesia is Accurate Accounting Enterprise. This research was conducted to evaluate the factors that influence the success of the accounting information system performance Accurate Accounting Enterprise using PIECES with six independent variables and the dependent variable is the performance, information and the data, economics, control and security, efficiency, service. This research was conducted on 45 respondents who use and benefit Accurate Accounting Enterprise at PT. Gunung Amal Solution International. Methods of data collection are observation, interviews, questionnaires, and literature. Data processing method used is multiple linear regression. From these results obtained on the analysis that the variable performance, information and data, economics, control and security, efficiency, service has a correlation value of 0.631 to the successful performance of the system, meaning that the variable independent and dependent in
\end{abstract}

Naskah diterima 15 Januari 2021; direvisi 6 Februari 2021; diterbitkan 28 Februari 2021 
this research have a strong relationship, calculated $F$ value of $13.353 R$ Square (R2) by $63 \%$ while the rest influenced by other factors. From the processing of these data showed that simultaneous, variable performance, information and the data, economics, control and security, efficiency, service significantly influence the success of the system performance. Partially, only the variable information and data that have a significant positive effect on the success of the performance of the system, while the performance, economics, control and security, efficiency, service has a significant negative effect on the success of the accounting information system performance Accurate Accounting Enterprise.

Keyword: Accounting Information Systems, Evaluation of Success Performance, Accurate Accounting Enterprise, PIECES.

\section{Pendahuluan}

Akuntansi yang merupakan pendukung penting dalam bisnis, telah mengalami perkembangan teknologi informasi yang cukup pesat. Dimana akuntansi adalah sistem informasi yang mengidentifikasi, mencatat, mengumpulkan, dan mengkomunikasikan data keuangan untuk tujuan pengambilan keputusan (Hery, 2014). Sistem akuntansi yang efektif memberikan tiga tujuan luas, yaitu (1) pelaporan internal ke manajer untuk perencanaan dan pengendalian kegiatan rutin; (2) pelaporan internal untuk perencanaan strategi; dan (3) untuk pihak eksternal yang meliputi pemegang saham, pemerintah, dan pihak luar lainnya. Ketigatiganya dihasilkan melalui pemrosesan data yang disebut transaksi akuntansi (Samryn, 2015).

Saat ini informasi merupakan bagian yang penting dan bermanfaat bagi manusia, kebutuhannya terus meningkat dari waktu ke waktu. Suatu informasi dapat dikatakan memiliki manfaat dalam proses pengambilan keputusan apabila informasi tersebut disajikan secara akurat, tepat waktu, dan relevan. Dengan kemajuan teknologi, keberadaan sistem informasi memberikan nilai tambah terhadap proses, produksi, kualitas, manajemen, pengambilan keputusan, dan pemecahan masalah serta keunggulan kompetitif yang tentu saja sangat berguna bagi kegiatan bisnis (Syaradila, 2017).

Relevansi nilai (value relevance) informasi akuntansi merupakan salah satu alat ukur dalam menilai kualitas informasi akuntansi. Kerelevanan adalah kemampuan informasi untuk membantu pemakai laporan keuangan dalam membedakan beberapa alternatif keputusan sehingga pemakai laporan keuangan dapat dengan mudah menentukan pilihan atau keputusan. Dalam penyusunan dan penyajian laporan keuangan menggunakan pedoman yaitu Prinsip Standar Akuntansi Keuangan (PSAK). Pedoman tersebut dibutuhkan dalam upaya untuk meningkatkan kebermanfaatan informasi yang disajikan dalam laporan keuangan (Sebrina \& Taqwa, 2017).

Sistem informasi akuntansi merupakan rangkaian suatu kegiatan untuk memproses input yang berupa transaksi atau suatu kejadian menjadi suatu bentuk catatan tertulis yang tertuang dalam jurnal akuntansi hingga menghasilkan output berupa laporan keuangan (Werthi \& Khrisdayanti, 2017). Salah satu sistem informasi akuntansi yang dapat mempermudah pengelolaan laporan keuangan adalah Accurate Accounting.

Accurate Accounting Software adalah program akuntansi dan keuangan yang dirancang untuk memenuhi kebutuhan perusahaan dalam hal pencatatan akuntansi dan keuangan yang sudah mengikuti standar PSAK di Indonesia. PT. Cipta Piranti Sejahtera berdiri pada 26 Oktober 1998 dan Cipta Piranti Sejahtera lebih di kenal dengan nama CPSSoft sebagai pengembangan software. Misi dalam bisnis adalah menyediakan software yang berkualitas tinggi untuk usaha kecil dan menengah dengan harga yang terjangkau. Kemudian CPSSoft meng-update software accurate beberapa kali sesuai dengan perkembangan jaman sampai dengan sekarang yang sudah di versi 5 dan mendukung untuk peraturan perpajakan yang terbaru, yaitu menggunakan e-faktur. Accurate Accounting Software dapat mengekspor transaksi ke bentuk .csv yang dapat diimpor ke aplikasi e-faktur (CPSSoft, 2015).

Transformasi digital telah mengubah Indonesia menjadi salah satu negara dengan pertumbuhan e-commerce yang sangat cepat seiring dengan peningkatan penggunaan smartphone dan infrastruktur 
telekomunikasi internet. Potensi pasar ecommerce dan bisnis aplikasi digital yang luas ke depan, mengundang para calon wirausaha untuk berlomba-lomba mendirikan perusahaan pemula atau lebih dikenal dengan start-up. Start-up merujuk pada perusahaan yang bergerak dengan memanfaatkan teknologi informasi dan internet karena biasanya beroperasi melalui website (Perdani, Dolorosa, \& Pulus, 2018).

Perkembangan start-up bisnis diharapkan mencapai keberhasilan yang tidak terlepas dari peran faktor internal bisnis yang mereka kelola. Faktor internal penting diteliti karena merupakan faktor penentu keberhasilan start-up bisnis. Aspek internal berupa biaya operational jika tidak dikelola dengan efisien akan menyebabkan terjadinya inefisiensi dan peningkatan biaya operasional yang pada akhirnya akan mengurangi profit start-up bisnis. Finance merupakan faktor internal yang membutuhkan analisis keuangan yang mendalam ketika mengelola dana start-up dengan tepat ketika terjadi kesalahan dalam pengelolaan keuangan akan berakibat pada keterpurukan keuangan start-up bisnis (Sitepu, 2017).

PT. Gunung Amal Solution International merupakan salah satu perusahaan start-up yang bergerak di bidang Jasa Konsultasi Teknologi dan Informasi. Dalam proses pengelolaan laporan keuangan, PT. Gunung Amal Solution International telah melakukan penyusunan laporan keuangan yang sesuai dengan Prinsip Standar Akuntansi Keuangan sehingga telah tersedianya informasi keuangan yang relevan dan akurat sebagai acuan pengambilan keputusan baik bagi pemilik perusahaan maupun bagi pihak-pihak eksternal dengan menggunakan aplikasi Accurate Accounting.

Sistem perlu dievaluasi guna mengetahui kesuksesan sistem secara teknik dan perilaku. Ada beberapa metode yang bisa digunakan untuk mengevaluasi suatu sistem. Evaluasi terhadap Accurate Accounting telah dilakukan dengan menggunakan beberapa model evaluasi, diantaranya Technology Acceptable Model dan DeLone \& McLane IS Success Model.

Pembahasan pada penelitian sistem informasi Accurate Accounting menggunakan metode evaluasi Technology Acceptable Model, menunjukan bahwa (1) user dipaksakan untuk menggunakan software Accurate (pressure to use), sehingga hal tersebut membantu user dalam memaksimalkan kegunaan software Accurate (perceived usefulness), (2) kemampuan menggunakan komputer yang dimiliki mahasiswa (computer self efficacy) dapat mempermudah user dalam menggunakan software Accurate (perceived ease of use), (3) software Accurate mudah digunakan (perceived ease of use), sehingga user dapat merasakan manfaat/kegunaan software tersebut (perceived usefulness), (4) software Accurate telah memberikan manfaat bagi user (perceived usefulness), sehingga software tersebut dapat diterima (behavioral intention to use), (5) software Accurate mudah untuk digunakan (perceived ease of use), sehingga software tersebut dapat diterima oleh user (behavioral intention to use) (Chalarce \& Arung, 2019).

Berdasarkan pembahasan pada penelitian kesuksesan sistem informasi Accurate Accounting menggunakan metode evaluasi DeLone \& MClean IS Success Model menunjukan bahwa ada dua variabel yang berpengaruh besar terhadap keberhasilan sistem informasi akuntansi Accurate yaitu, variabel kualitas sistem sebesar 9.3339 dan variabel kepuasan pengguna sebesar 23.9353. Dapat diartikan bahwa kualitas sistem dari sistem informasi Accurate sudah baik sehingga pengguna merasa puas untuk memakai sistem ini (Hudin \& Riana, 2016).

Evaluasi terhadap sistem informasi dapat diketahui dengan menggunakan suatu acuan, salah satunya yaitu dengan metode analisis PIECES yang meliputi kinerja (performance), informasi dan data (information and data), nilai ekonomis (economics), pengendalian dan pengamanan (control and security), efesiensi (efficiency) dan pelayanan (service). Metode PIECES memiliki keunggulan jika dibandingkan dengan metode lain, misalnya dengan metode Technology Acceptance Model (TAM). Penerimaan individual terhadap sistem teknologi informasi ditentukan oleh dua konstruk utama TAM yaitu kegunaan persepsian (perceived usefulness) dan kemudahan penggunaan persepsian (perceived ease of use) (Chalarce \& Arung, 2019). DeLone \& McLane Model yang menggunakan tiga variabel untuk menentukan pengaruh variabel penggunaan dan kepuasan pengguna yaitu variable 
kualitas informasi, kualitas sistema dan kualitas pelayanan (Hudin \& Riana, 2016).

Metode PIECES sebagai alat analisis sistem, suatu sistem secara detail dan menyeluruh akan mendapatkan perhatian khusus, sehingga kekuatan dan kelemahan sistem dapat diketahui untuk nantinya dijadikan acuan bagi kemajuan sistem selanjutnya (Supriyatna, 2017).

Sehubungan dengan adanya latar belakang yang telah diuraikan di atas, penulis mengambil judul "Evaluasi Kinerja Sistem Informasi Akuntansi Accurate Accounting Enterprise Menggunakan Metode PIECES pada PT. Gunung Amal Solution International", dan diharapkan dapat memberikan gambaran kinerja sistem informasi akuntansi Accurate Accounting Enterprise untuk menghasilkan suatu laporan keuangan dengan cepat, mudah dan akurat di perusahaan.

\section{Metode Penelitian Tahapan Penelitian}

Tahapan dalam penelitian ini dapat dilihat pada Gambar 1.

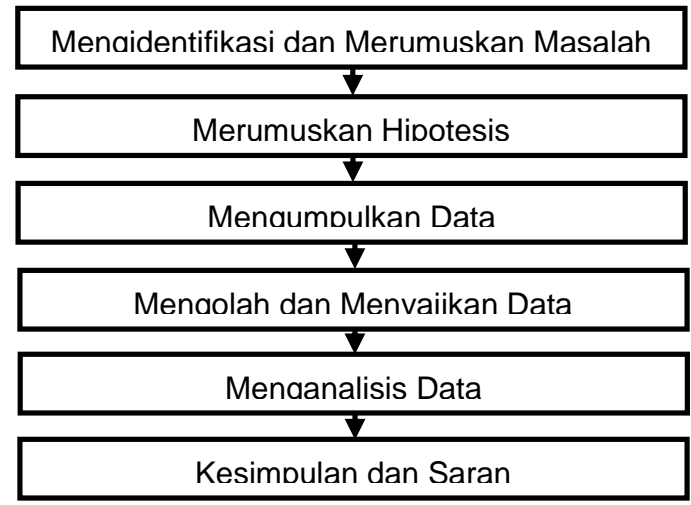

Gambar 1. Tahapan Penelitian

\section{Model PIECES}

PIECES pertama kali dikenalkan oleh (Wetherbe \& Vitalari, 2012), PIECES merupakan metode evaluasi yang terdiri dari aspek (variabel) Performance, Information and Data, Economic, Control and Security, Efficiency, and Service.

Sistem perlu dievaluasi guna mengetahui kesuksesan sistem secara teknik dan perilaku sehingga perlu dilakukan analisis terhadap kinerja, informasi, ekonomi, keamanan, efisiensi, dan pelayanan dari sistem informasi tersebut. Metode analisis PIECES ini akan memudahkan kita mendapatkan beberapa masalah dan akhirnya dapat ditentukan masalah utamanya.

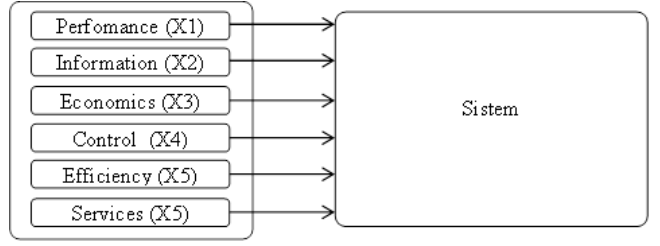

Gambar 2. Model Penelitian PIECES

Dalam (Supriyatna, 2017), PIECES terdapat enam buah variabel yang digunakan untuk menganalisis sistem informasi, yaitu:

1. Keandalan (Performance). Analisis ini dilakukan untuk mengetahui kinerja sebuah sistem, apakah berjalan dengan baik atau tidak. Kinerja ini dapat diukur dari jumlah temuan data yang dihasilkan dan seberapa cepat suatu data dapat ditemukan. Indikator yang mempengaruhi :

a. Throughput, dimana sistem ini dinilai dari banyaknya kerja yang dilakukan pada beberapa periode waktu.

b. Respon time, yaitu delay rata-rata antara transaksi dan respon dari transaksi tersebut.

c. Audibilitas, yaitu kecocokan dimana keselarasan terhadap standar dapat diperiksa.

d. Kelaziman komunikasi, yaitu tingkat dimana interface sandar, protokol, dan bandwith digunakan.

e. Kelengkapan, yaitu derajat dimana implementasi penuh dari fungsi yang diharapkan tercapai.

f. Konsistensi, yaitu penggunaan desain dan teknik dokumentasi yang seragam pada keseluruhan proyek pengembangan perangkat lunak.

g. Toleransi kesalahan, yaitu kerusakan yang terjadi pada saat program mengalami kesalahan.

2. Data dan Informasi (Information and data). Dalam sebuah temuan data pasti akan dihasilkan sebuah informasi yang akan ditampilkan, analisis ini digunakan untuk mengetahui seberapa banyak dan seberapa jelas informasi yang akan dihasilkan untuk satu pencarian.
a. Accurancy (akurat) dimana informasi yang dihasilkan memiliki ketepatan yang tinggi.
b. Relevansi informasi, dimana informasi yang dihasilkan sesuai dengan kebutuhan. 
c. Penyajian informasi, dimana informasi yang disajikan dalam bentuk yang sesuai dan mudah diintepretasikan.

d. Fleksibilitas data, dimana informasi mudah disesuaikan dengan kebutuhan.

3. Nilai Ekonomis (Economics). Analisis ini dilakukan untuk mengetahui apakah suatu sistem itu tepat diterapkan pada suatu lembaga informasi dilihat dari segi finansial dan biaya yang dikeluarkan. Hal ini sangat penting karena suatu sistem juga dipengaruhi oleh besarnya biaya yang dikeluarkan.

a. Reusabilitas, tingkat dimana sebuah program atau bagian dari program tersebut dapat digunakan kembali didalam aplikasi yang lainnya.

b. Sumber daya, jumlah sumber daya yang digunakan dalam pengembangan sistem, meliputi sumber daya manusia serta sumber daya ekonomi.

4. Pengendalian dan Pengamanan (Control and Security). Dalam suatu sistem perlu diadakan sebuah control atau pengawasan agar sistem itu berjalan dengan baik. Analisis ini digunakan untuk mengetahui sejauh mana pengawasan dan kontrol yang dilakukan agar sistem tersebut berjalan dengan baik.

a. Integritas, tingkat dimana akses ke perangkat lunak atau data oleh orang yang tidak berhak dapat dikontrol.

b. Keamanan, yaitu mempunyai mekanisme yang mengontrol dan melindungi program.

5. Efisiensi (Efficiency). Efisiensi dan efektivitas sebuah sistem perlu dipertanyakan dalam kinerja dan alasan mengapa sistem itu dibuat. Sebuah sistem harus bisa secara efisien menjawab dan membantu suatu permasalahan khususnya dalam hal otomasi. Analisis ini dilakukan untuk mengetahui apakah suatu sistem itu efisien atau tidak, dengan input yang sedikit bisa menghasilkan sebuah output yang memuaskan.

a. Usabilitas, usaha yang dibutuhkan untuk mempelajari, mengoperasikan, menyiapkan input, dan mengintepretasikan output suatu program. b. Maintanabilitas, usaha yang diperlukan untuk mencari dan membetulkan kesalahan pada sebuah program.

6. Pelayanan (Service). Peningakatan pelayanan memperlihatkan kategori yang beragam. Peningkatan pelayanan yang lebih baik bagi manajemen, user dan bagian lain merupakan simbol kualitas dari suatu sistem informasi.

a. Akurasi yaitu ketelitian komputasi dan control.

b. Reliabilitas, tingkat dimana sebuah program dapat dipercaya melakukan fungsi yang diminta.

c. Kesederhaan yaitu tingkat dimana sebuah program dapat dipahami tanpa kesukaran.

\section{Accurate Accounting Enterprise}

Accurate Accounting

Software

adalah program akuntansi dan keuangan yang dirancang untuk memenuhi kebutuhan perusahaan dalam hal pencatatan akuntansi dan keuangan yang sudah mengikuti standar PSAK di Indonesia. PT. Cipta Piranti Sejahtera berdiri pada 26 Oktober 1998 dan Cipta Piranti Sejahtera lebih di kenal dengan nama CPSSoft sebagai pengembangan software. Misi dalam bisnis adalah menyediakan software yang berkualitas tinggi untuk usaha kecil dan menengah dengan harga yang terjangkau. Kemudian CPSSoft meng-update software accurate beberapa kali sesuai dengan perkembangan jaman sampai dengan sekarang yang sudah di versi 5 . Versi 5 yang saat ini ada sudah support untuk peraturan perpajakan yang terbaru, yaitu menggunakan e-faktur. Accurate Accounting Software dapat mengekspor transaksi ke bentuk .csv yang dapat diimpor ke aplikasi e-faktur (CPSSoft, 2015).

Accurate Accounting Software Versi 5 tampil dengan tampilan dan fitur baru yang lebih dinamis, lebih praktis, dan lebih interaktif dengan tetap mempertahankan sifat utama Accurate yaitu mudah digunakan (user friendly) dan keakurasian yang tinggi, Accurate 5 memberikan lebih banyak lagi fitur dan keunggulan yang akan membantu dalam menjalankan usaha semakin lebih mudah, efektif dan efesien.

\section{Instrumen Penelitian}

Instrumen penelitian dalam evaluasi kinerja sistem informasi akuntansi Accurate Accounting Enterprise ini berupa angket Kuesioner yang diberikan terhadap responden di lingkungan PT. Gunung Amal 
Solution International disebut dengan instrumen sebagai fungsi subtitusi. Penyusunan pertanyaan angket Kuesioner didasarkan pada variabel-variabel yang terkait seperti kinerja (performance), informasi dan data (information and data), nilai ekonomis (economics), pengendalian dan pengamanan (control and security), efesiensi (efficiency), dan pelayanan (service) dengan metode PIECES yang telah disusun sebelumnya. Kemudian atas dasar variabel-variabel yang mempengaruhi dalam metode PIECES dikembangkan dalam indikator-indikator dan selanjutnya dikembangkan dalam butir pertanyaan atau pernyataan.

Variabel penelitian adalah suatu atribut atau sifat atau nilai dari orang, objek atau kegiatan yang mempunyai variasi tertentu yang ditetapkan oleh peneliti untuk dipelajari dan ditarik kesimpulannya.

Variabel yang digunakan dalam penelitian ini ada 2 macam yaitu variabel bebas (independent) dan variabel terikat (dependent).

a. Variabel Bebas (Independent Variable)

Variabel bebas (Independent Variable) adalah variabel yang mempengaruhi variabel terikat secara positif ataupun negatif. Variabel bebas dalam penelitian ini adalah :
1) Variabel $(X 1)=$ (Performance)
Kinerja
2) Variabel $(X 2)=$ Informasi dan data (Information and data)
3) Variabel $(\mathrm{X} 3)=$ Nilai ekonomis (Economic)
4) Variabel $(\mathrm{X} 4) \quad=$ Pengendalian dan
pengamanan (Control and security)
5) Variabel (X5) = $\quad$ Efesiensi (Efficiency)
6) Variabel $(X 6)=$ Pelayanan (Service).

b. Variabel Terkait (Dependen Variable)

Variabel Terkait (Dependen Variable) adalah variabel yang dipengaruhi oleh variabel bebas. Variabel terkait dalam penelitian ini yaitu keberhasilan kinerja sistem informasi akuntansi Accurate Accounting Enterprise.

Variabel harus didefinisikan secara operasional agar lebih mudah dicari hubungannya antara satu variabel dengan lainnya dan pengukurannya. Tanpa operasionalisasi variabel, peneliti akan mengalami kesulitan dalam menentukan pengukuran hubungan antar variabel yang masih bersifat konseptual.
Operasional variabel diperlukan untuk menentukan jenis dan indikator variabel-variabel dalam penelitian. Dan operasional variabel dimaksudkan untuk menemukan skala pengukuran dari masingmasing variabel, sehingga pengujian dengan alat bantu stastik dapat dilakukan dengan benar. Variabel independen dan variabel dependen dalam penelitian ini adalah :

Pada Tabel 1. adalah definisi operasional variabel dalam penelitian ini.

Tabel 1. Definisi Operasionalisasi Variabel

\begin{tabular}{|c|c|c|}
\hline Variabel & & Indikator \\
\hline \multirow{6}{*}{$\begin{array}{c}\mathrm{X}_{1} \\
\text { Kinerja / } \\
\text { Perform } \\
\text { ance } \\
(\mathrm{P})\end{array}$} & P1 & $\begin{array}{lc}\text { Sistem } & \text { informasi } \\
\text { akuntansi } & \text { Accurate } \\
\text { Accounting } & \text { Enterprise } \\
\text { sangat mudah diakses } \\
\text { oleh pengguna. }\end{array}$ \\
\hline & P2 & $\begin{array}{lr}\text { Sistem informasi } \\
\text { akuntansi } & \text { Accurate } \\
\text { Accounting Enterprise } \\
\text { dapat mengoperasikan } \\
\text { sejumlah perintah dalam } \\
\text { waktu yang relatif } \\
\text { singkat, } \\
\text { mengalami hambatan. }\end{array}$ \\
\hline & P3 & $\begin{array}{lr}\text { Sistem } & \text { informasi } \\
\text { akuntansi } & \text { Accurate } \\
\text { Accounting } & \text { Enterprise } \\
\text { dalam merespons suatu } \\
\text { perintah pembatalan } \\
\text { maupun permintaan } \\
\text { terhadap suatu transaksi } \\
\text { dilakukan dengan cepat. }\end{array}$ \\
\hline & P4 & $\begin{array}{lr}\text { Jumlah data yang dapat } \\
\text { diproses } \\
\text { informasi } & \text { akuntansi } \\
\text { Accurater Accounting } \\
\text { Enterprise pada } & \text { satuan } \\
\text { waktu sudah } & \text { sesuai } \\
\text { dengan } & \text { yang } \\
\text { diharapkan. } & \end{array}$ \\
\hline & P5 & $\begin{array}{l}\text { Pada saat sistem } \\
\text { informasi akuntansi } \\
\text { Accurate Accounting } \\
\text { Enterprise digunakan } \\
\text { secara bersamaan, } \\
\text { kinerja sistem informasi } \\
\text { tetap berjalan stabil. }\end{array}$ \\
\hline & P6 & $\begin{array}{l}\text { Total waktu yang } \\
\text { dibutuhkan dalam } \\
\text { melakukan pengolahan } \\
\text { dataran } \\
\text { menghasilkan informasi } \\
\text { sudah dilakukan dengan } \\
\text { cepat. }\end{array}$ \\
\hline
\end{tabular}




\begin{tabular}{|c|c|c|}
\hline \multirow{9}{*}{$\begin{array}{l}\mathrm{X}_{2} \\
\text { Informas } \\
\text { i dan } \\
\text { Data / } \\
\text { Informati } \\
\text { on and } \\
\text { Data } \\
\text { (I) }\end{array}$} & I1 & $\begin{array}{lr}\text { Data yang } & \text { disimpan } \\
\text { oleh sistem } & \text { informasi } \\
\text { akuntansi } & \text { Accurate } \\
\text { Accounting } & \text { Enterprise } \\
\text { sudah tersimpan sesuai } \\
\text { dengan rrang } \\
\begin{array}{lr}\text { dimasukkan ke dalam } \\
\text { sistem. }\end{array}\end{array}$ \\
\hline & 12 & $\begin{array}{lr}\text { Sistem informasi } \\
\text { akuntansi Accurate } \\
\text { Accounting Enterprise } \\
\text { tidak dapat menyimpan } \\
\text { data yang bukan } \\
\text { seharusnya. }\end{array}$ \\
\hline & 13 & $\begin{array}{l}\text { Data yang mengandung } \\
\text { kesalahan atau data } \\
\text { yang tidak benar tidak } \\
\text { dapat disimpan oleh } \\
\text { sistem informasi } \\
\text { akuntansi Accurate } \\
\text { Accounting Enterprise. }\end{array}$ \\
\hline & 14 & $\begin{array}{lr}\text { Sistem informasi } & \text { infurantansi } \\
\text { akuntansi } & \text { Accurate } \\
\text { Accounting } & \text { Enterprise } \\
\text { tidak dapat menyimpan } & \text { data yang sama } \\
\text { data } & \text { sehingga ridak } \\
\text { menimbulkan duplikasi } & \text { atau redudansi data. }\end{array}$ \\
\hline & 15 & $\begin{array}{lr}\text { Informasi } & \text { yang } \\
\text { dihasilkan oleh } & \text { sistem } \\
\text { informasi sudah } & \text { sesuai } \\
\text { dengan } & \text { yang } \\
\text { dibutuhkan. } & \\
\end{array}$ \\
\hline & 16 & $\begin{array}{lr}\text { Informasi } & \text { yang } \\
\text { dihasilkan } & \text { oleh sistem } \\
\text { informasi } & \text { akuntansi } \\
\text { Accurate } & \text { Accounting } \\
\text { Enterprise } & \text { tepat pada } \\
\text { waktunya. } & \\
\end{array}$ \\
\hline & 17 & $\begin{array}{l}\text { Format informasi yang } \\
\text { dihasilkan oleh sistem } \\
\text { informasi akuntansi } \\
\text { Accurate Accounting } \\
\text { Enterprise bermanfaat } \\
\text { dan dapat digunakan } \\
\text { sebagaimana mestinya } \\
\text { oleh pengguna. }\end{array}$ \\
\hline & 18 & $\begin{array}{l}\text { Data yang diolah oleh } \\
\text { sistem informasi } \\
\text { akuntansi Accurate } \\
\text { Accounting Enterprise } \\
\text { sudah tersimpan ke } \\
\text { dalam satu media } \\
\text { penyimpanan. }\end{array}$ \\
\hline & 19 & $\begin{array}{l}\text { Informasi yang disajikan } \\
\text { sistem informasi }\end{array}$ \\
\hline
\end{tabular}

\begin{tabular}{|c|c|c|}
\hline & & $\begin{array}{lr}\text { akuntansi } & \text { Accurate } \\
\text { Accounting } & \text { Enterprise } \\
\text { mudah untuk dipelajari } \\
\text { dan dipahami. }\end{array}$ \\
\hline & I10 & $\begin{array}{lr}\text { Informasi } & \text { yang } \\
\text { dihasilkan } & \text { sistem } \\
\text { informasi } & \text { akuntansi } \\
\text { Accurate } & \text { Accounting } \\
\text { Enterprise } & \text { dapat } \\
\text { diandalkan/dipercaya. }\end{array}$ \\
\hline \multirow{3}{*}{$\begin{array}{c}\mathrm{X}_{3} \\
\text { Nilai } \\
\text { Ekonomi } \\
\mathrm{s} / \\
\text { Economi } \\
\text { CS } \\
(E C)\end{array}$} & $\begin{array}{c}\text { EC } \\
1\end{array}$ & $\begin{array}{l}\text { Biaya yang dikeluarkan } \\
\text { oleh perusahaan } \\
\text { menjadi lebih ringan } \\
\text { dengan adanya sistem } \\
\text { informasi akuntansi } \\
\text { Accurate Accounting } \\
\text { Enterprise dibandingkan } \\
\text { dengan menggunakan } \\
\text { cara konvensional. }\end{array}$ \\
\hline & $\begin{array}{c}E C \\
2\end{array}$ & $\begin{array}{lr}\text { Pada saat } & \text { penerapan } \\
\text { sistem } & \text { informasi } \\
\text { akuntansi } & \text { Accurate } \\
\text { Accounting } & \text { Enterprise, } \\
\text { biaya yang } & \text { dikeluarkan } \\
\text { perusahaan } & \text { cukup } \\
\text { tinggi. } & \\
\end{array}$ \\
\hline & $\begin{array}{c}E C \\
3\end{array}$ & $\begin{array}{l}\text { Ada perubahan yang } \\
\text { signifikan dalam hal } \\
\text { perkembangan dan } \\
\text { pertumbuhan dengan } \\
\text { adanya sistem informasi } \\
\text { akuntansi Accurate } \\
\text { Accounting Enterprise. }\end{array}$ \\
\hline \multirow{4}{*}{$\begin{array}{c}\mathrm{X}_{4} \\
\text { Pengen } \\
\text { dalian } \\
\text { dan } \\
\text { Pengam } \\
\text { anan / } \\
\text { Control } \\
\text { and } \\
\text { Security } \\
\text { (C) }\end{array}$} & $\mathrm{C} 1$ & 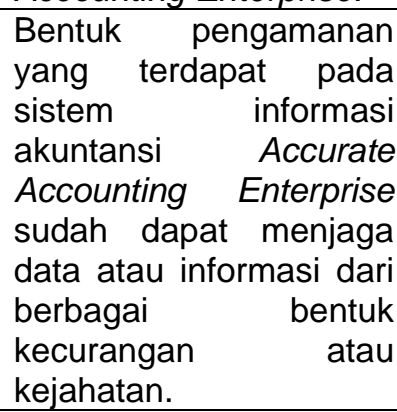 \\
\hline & C2 & $\begin{array}{lc}\text { Terdapat pengontrolan } \\
\text { terpusat } & \text { terhadap } \\
\text { penggunaan data. }\end{array}$ \\
\hline & C3 & $\begin{array}{lr}\text { Sistem } & \text { pengamanan } \\
\text { pada sistem } & \text { informasi } \\
\text { akuntansi } & \text { Accurate } \\
\text { Accounting } & \text { Enterprise } \\
\text { sudah baik. } & \\
\end{array}$ \\
\hline & C4 & $\begin{array}{lr}\text { Manajemen dalam } \\
\text { memberikan otorisasi } \\
\text { dan menentukan } \\
\text { pengendalian akses } \\
\text { terhadap penggunaan } \\
\text { dan pengoperasian }\end{array}$ \\
\hline
\end{tabular}

http://ejurnal.ars.ac.id/index.php/jti 


\begin{tabular}{|c|c|c|}
\hline & & sistem sudah jelas. \\
\hline & C5 & $\begin{array}{l}\text { Media penyimpanan } \\
\text { aman dari perusakan } \\
\text { dan kecelakaan. }\end{array}$ \\
\hline & C6 & $\begin{array}{l}\text { Media penyimpanan } \\
\text { dapat } \\
\text { mengorganisasikan data } \\
\text { dengan baik. }\end{array}$ \\
\hline & $\mathrm{C} 7$ & $\begin{array}{l}\text { Dalam pemeliharaan } \\
\text { sistem, akuntan internal } \\
\text { tidak mengalami } \\
\text { kesulitan baik dari segi } \\
\text { biaya manan } \\
\text { pelaksanaanya. maupun }\end{array}$ \\
\hline \multirow{3}{*}{$\begin{array}{c}X_{5} \\
\text { Efisiensi } \\
/ \\
\text { Efficienc } \\
y \\
(\mathrm{EF})\end{array}$} & $\begin{array}{c}\text { EF } \\
1\end{array}$ & $\begin{array}{l}\text { Sistem yang digunakan } \\
\text { sekarang lebih } \\
\text { meringankan pengguna } \\
\text { baik dari segi biaya dan } \\
\text { waktu. }\end{array}$ \\
\hline & $\begin{array}{c}E F \\
2\end{array}$ & $\begin{array}{lr}\text { Penggunaan } & \text { sistem } \\
\text { informasi } & \text { akuntansi } \\
\text { Accurate } & \text { Accounting } \\
\text { Enterprise } & \text { paling } \\
\text { berperan dalam hal } \\
\text { peningkatan } \\
\text { perusahaan. }\end{array}$ \\
\hline & $\begin{array}{c}E F \\
3\end{array}$ & $\begin{array}{l}\text { Dalam mengoperasikan } \\
\text { sistem pada } \\
\text { kegiatan/aktivitas } \\
\text { akuntan internal sehari- } \\
\text { hari, apakah sistem } \\
\text { dapat menghasilkan } \\
\text { output yang sesuai } \\
\text { dengan waktu dan } \\
\text { material yang minimal. }\end{array}$ \\
\hline \multirow{5}{*}{$\begin{array}{c}\mathrm{X}_{6} \\
\text { Pelayan } \\
\text { an / } \\
\text { Service } \\
\text { (S) }\end{array}$} & S1 & $\begin{array}{lr}\text { Akuntan } & \text { internal } \\
\text { memberikan } & \text { bantuan } \\
\text { kepada } & \text { pengguna } \\
\text { dalam } & \text { penggunaan } \\
\text { sistem } & \text { informasi } \\
\text { akuntansi } & \text { Accurate } \\
\text { Accounting } & \text { Enterprise. }\end{array}$ \\
\hline & S2 & $\begin{array}{lr}\text { Sistem } & \text { informasi } \\
\text { akuntansi } & \text { Accurate } \\
\text { Accounting Enterprise } \\
\text { mudah dipelajari dan } \\
\text { dipahami. }\end{array}$ \\
\hline & S3 & $\begin{array}{lc}\text { Sistem } & \text { informasi } \\
\text { akuntansi } & \text { Accurate } \\
\text { Accounting } & \text { Enterprise } \\
\text { mudah digunakan. }\end{array}$ \\
\hline & S4 & $\begin{array}{lc}\text { Sistem } & \text { informasi } \\
\text { akuntansi } & \text { Accurate } \\
\text { Accounting } & \text { Enterprise } \\
\text { fleksibel jika } & \text { digunakan } \\
\text { untuk situasi yang baru. }\end{array}$ \\
\hline & S5 & informasi \\
\hline
\end{tabular}

\begin{tabular}{|c|c|}
\hline & $\begin{array}{l}\text { akuntansi } \text { Accurate } \\
\text { Accounting Enterprise } \\
\text { dapat dirubah secara } \\
\text { fleksibel. }\end{array}$ \\
\hline S6 & $\begin{array}{lr}\text { Sistem } & \text { informasi } \\
\text { akuntansi } & \text { Accurate } \\
\text { Accounting } & \text { Enterprise } \\
\text { terkoordinasi } & \text { dan } \\
\text { terintegrasi } & \text { dengan } \\
\text { sistem yang lain. } & \\
\end{array}$ \\
\hline S7 & $\begin{array}{lr}\text { Sistem } & \text { informasi } \\
\text { akuntansi } & \text { Accurate } \\
\text { Accounting } & \text { Enterprise } \\
\text { dapat memberikan } & \text { mepuasan anda sebagai } \\
\text { pengguna r yang } & \\
\text { membutuhkan informasi }\end{array}$ \\
\hline
\end{tabular}

\section{Metode Pengumpulan Data}

Metode Pengumpulan Data adalah cara atau teknik yang dapat digunakan oleh peneliti untuk mengumpulkan data. Dalam penelitian ini metode pengumpulan data yang digunakan adalah angket Kuesioner.

\section{Populasi dan Sampel}

Sampel adalah bagian dari jumlah dan karakteristik yang dimiliki oleh populasi. Untuk itu sampel yang diambil dari populasi harus betul-betul representative (mewakili). Dalam penelitian ini tidak mungkin semua populasi dapat penulis teliti.

Hal ini disebabkan beberapa faktor, diantaranya keterbatasan biaya, keterbatasan tenaga dan keterbatasan waktu yang tersedia. Untuk itu sampel dari peneliti harus betul-betul representatif (mewakili). Sampel yang digunakan dalam penelitian ini adalah Akuntan Internal dan Staff PT. Gunung Amal Solution International sebanyak 45 responden pengguna kinerja Sistem Informasi Akuntansi Accurate Accounting Enterprise.

Dalam pengambilan sampel dari populasi harus dilakukan secara akurat dan efektif sehingga diperoleh sampel (contoh) yang benar-benar dapat berfungsi sebagai contoh atau dapat menggambarkan keadaan populasi sebenarnya dari objek penelitian.

Teknik Sampling adalah merupakan teknik pengambilan sampel. Teknik sampling dibagi menjadi dua kelompok yaitu, Probability Sampling dan Nonprobability sampling.

Teknik pengumpulan sampel yang digunakan dalam penelitian ini menggunakan pendekatan non probability sampling dengan teknik purposive sampling. 
Dimana purposive sampling merupakan pemilihan sampel yang didasarkan atas pertimbangan tertentu agar mendapatkan informasi yang akurat dengan tujuan untuk mendapatkan sampel yang bersifat representative (mewakili).

Ukuran sampel yang layak dalam penelitian adalah antara 30 sampai dengan 500. Populasi dalam penelitian ini adalah Staff PT. Gunung Amal Solution International. Jumlah ukuran sampel yang diambil oleh peneliti sebanyak 45 responden. Jumlah ini memenuhi minimum kriteria pengambilan sampel. Teknik pengambilan sampel yang digunakan dalam penelitian ini adalah dengan purposive sampling menggunakan rumus slovin dengan tingkat kesalahan 5\%.

$n=\mathrm{N} /\left(1+\mathrm{Ne}^{\wedge} 2\right)$

Sumber : (Asari, Toloh, \& Sangari, 2018)

$\mathrm{n} \quad=\mathrm{N} /(1+(\mathrm{N} \times \mathrm{e} 2))$

$\mathrm{n} \quad=50 /(1+(50 \times 0,052))$

$\mathrm{n} \quad=50 /(1+(50 \times 0,0025))$

$\mathrm{n} \quad=50 /(1+(0,125))$

$\mathrm{n} \quad=50 / 1,125$

$\mathrm{n} \quad=44,44$

$\mathrm{n}=45$

Jumlah responden untuk dijadikan sampel ini diambil dari hasil pembulatan ke atas untuk mengurangi kesalahan.

Metode Analisis Data

Analisis data adalah mengelompokkan data berdasarkan variabel dan jenis responden, mentabulasi data berdasarkan variabel dari seluruh responden, menyajikan data tiap yang diteliti, melakukan perhitungan untuk menjawab rumusan masalah, dan melakukan perhitungan untuk menguji hipotesis yang telah diajukan. Metode analisis data dalam penelitian adalah Analisis Deskriptif dan Analisis Statistika.

\section{Hasil Dan Pembahasan}

\subsection{Profil Responden}

Penelitian ini menggunakan data

hasil penelitian yang diperoleh dari penyebaran kuesioner yang berupa google form kepada responden. Data yang diperoleh dari penyebaran kuesioner ini merupakan data primer penelitian. Sampel dari penelitian ini berjumlah 45 responden, yaitu Karyawan PT. Gunung Amal Solution International. Setiap responden yang menggunakan Accurate Accounting Enterprise ini memiliki karakteristik yang berbeda-beda. Karakteristik responden menggambarkan keadaan responden yang mengetahui tingkat keberhasilan Kinerja Accurate Accounting Enterprise di PT. Gunung Amal Solution International. Dalam penelitian ini, karakteristik responden dibedakan berdasarkan jenis kelamin, usia, dan tingkat wawasan, pengetahuan serta pengalaman.

\section{Karakteristik Responden Berdasarkan Jenis Kelamin}

Karakteristik responden berdasarkan jenis kelamin yaitu 45 karyawan atau $77,78 \%$ adalah laki - laki, sedangkan 10 karyawan atau $22,22 \%$ adalah perempuan.

\section{Karakteristik Responden Berdasarkan Usia}

Karakteristik responden berdasarkan usia didominasi oleh kelompok usia kurang dari 24 tahun dengan jumlah 28 orang atau $62,22 \%$. Kelompok usia kedua terbanyak yaitu kelompok usia 24 - 30 tahun dengan jumlah 10 orang atau $22,22 \%$. Kelompok usia 30 - 36 tahun berjumlah 4 orang atau $8,89 \%$. Kelompok usia 36 - 42 tahun berjumlah 2 orang atau $4,44 \%$. Sedangkan kelompok usia lebih dari 42 tahun adalah kelompok usia yang paling rendah dengan jumlah 1 orang atau 2,22\%.

\section{Karakteristik Responden Berdasarkan wawasan, pengetahuan dan pengalaman}

Karakteristik responden berdasarkan wawasan, pengetahuan dan pengalaman didominasi oleh kelompok yang memiliki wawasan, pengetahuan dan pengalaman dengan jumlah 32 orang atau $71,11 \%$. Sedangkan yang menjawab ragu-ragu atas wawasan, pengetahuan dan pengalaman yang dimiliki berjumlah 13 orang atau $28,89 \%$. Karyawan yang memiliki wawasan, pengetahuan dan pengalaman ini dapat menentukan akurasi penyebaran kuesioner penilaian keberhasilan kinerja sistem informasi akuntansi Accurate Accounting Enterprise dalam menghasilkan laporan keuangan yang efektif dan efesien pada PT. Gunung Amal Solution International.

\subsection{Pembahasan}

Setelah mennguji model yang digunakan terhadap uji validitas, uji Reliabilitas, uji asumsi klasik dan uji menggunakan model regresi linear berganda seperti: uji koefisien determinasi, uji $t$, uji $f$ serta menguji hipotesis dari penelitian tahap selanjutnya adalah pembahasan hasil penelitian: 
1. Analisis Kinerja (Performance) Memiliki Pengaruh Negatif Signifikan Terhadap Keberhasilan Kinerja Sistem Informasi Akuntansi Accurate Accounting Enterprise pada PT. Gunung Amal Solution International Dari hasil penelitian ini diketahui bahwa variabel Kinerja (Performance) memiliki hubungan negative signifikan terhadap Keberhasilan Kinerja Sistem Informasi Akuntansi Accurate, tingkat hubungan dengan nilai t hitung sebesar $-0,828$ dan nilai signifikasi dari Kinerja (Performance) $(P)=0,413$. Sehingga semakin baik variabel Kinerja (Performance) maka dapat meningkatkan Keberhasilan Kinerja Sistem Informasi Akuntansi Accurate Accounting Enterprise pada PT. Gunung Amal Solution International.

2. Informasi dan Data (Information and Data)

Memiliki Pengaruh Positif Signifikan Terhadap Keberhasilan Kinerja Sistem Informasi Akuntansi Accurate Accounting Enterprise pada PT. Gunung Amal Solution International. Dari hasil penelitian ini diketahui bahwa variabel Informasi dan Data (Information and Data) memiliki hubungan negatif signifikan terhadap Keberhasilan Kinerja Sistem Informasi Akuntansi Accurate Accounting Enterprise, tingkat hubungan dengan nilai $t$ hitung sebesar 6,572 dan nilai signifikasi dari Informasi dan Data (Information and Data) $(\mathrm{I})=0,000$. Sehingga, semakin baik variabel Informasi dan Data (Information and Data) maka dapat meningkatkan Keberhasilan Kinerja Sistem Informasi Akuntansi Accurate Accounting Enterprise pada PT. Gunung Amal Solution International.

3. Nilai Ekonomi (Economic)

Memiliki Pengaruh Negatif Signifikan Terhadap Keberhasilan Kinerja Sistem Informasi Akuntansi Accurate Accounting Enterprise pada PT. Gunung Amal Solution International. Dari hasil penelitian ini diketahui bahwa variabel Nilai Ekonomi (Economic) memiliki hubungan negatif signifikan terhadap Keberhasilan Kinerja Sistem Informasi Akuntansi Accurate Accounting Enterprise, tingkat hubungan dengan nilai t hitung sebesar $-1,437$ dan nilai signifikasi dari Nilai
Ekonomi (Economic) $(\mathrm{EC})=0,159$. Sehingga, semakin baik variabel Nilai Ekonomi (Economic) maka dapat meningkatkan Keberhasilan Kinerja Sistem Informasi Akuntansi Accurate Accounting Enterprise pada PT. Gunung Amal Solution International.

4. Pengendalian dan Pengamanan (Control and Security)

Memiliki Pengaruh Negatif Signifikan Terhadap Keberhasilan Kinerja Sistem Informasi Akuntansi Accurate Accounting Enterprise pada PT. Gunung Amal Solution International. Dari hasil penelitian ini diketahui bahwa variabel Pengendalian dan Pengamanan (Control and Security) memiliki hubungan negatif signifikan terhadap Keberhasilan Kinerja Sistem Informasi Akuntansi Accurate Accounting Enterprise, tingkat hubungan dengan nilai t hitung sebesar $-0,166$ dan nilai signifikasi dari Pengendalian dan Pengamanan (Control and Security) (C) $=0,869$. Sehingga, semakin baik variabel Pengendalian dan Pengamanan (Control and Security) maka dapat meningkatkan Keberhasilan Kinerja Sistem Informasi Akuntansi Accurate Accounting Enterprise pada PT. Gunung Amal Solution International.

5. Efektifitas (Efficiency)

Memiliki Pengaruh Negatif Signifikan Terhadap Keberhasilan Kinerja Sistem Informasi Akuntansi Accurate Accounting Enterprise pada PT. Gunung Amal Solution International. Dari hasil penelitian ini diketahui bahwa variabel Efektifitas (Efficiency) memiliki hubungan negatif signifikan terhadap Keberhasilan Kinerja Sistem Informasi Akuntansi Accurate Accounting Enterprise, tingkat hubungan dengan nilai t hitung sebesar 1,596 dan nilai signifikasi dari Efektifitas (Efficiency) $(\mathrm{EF})=0,119$. Sehingga, semakin baik variabel Efektifitas (Efficiency) maka dapat meningkatkan Keberhasilan Kinerja Sistem Informasi Akuntansi Accurate Accounting Enterprise pada PT. Gunung Amal Solution International.

6. Pelayanan (Service) Memiliki Pengaruh Negatif Signifikan Terhadap Keberhasilan Kinerja Sistem Informasi Akuntansi Accurate Accounting Enterprise pada 
PT. Gunung Amal Solution International. Dari hasil penelitian ini diketahui bahwa variabel Pelayanan (Service) memiliki hubungan negatif signifikan terhadap Keberhasilan Kinerja Sistem Informasi Akuntansi Accurate Accounting Enterprise, tingkat hubungan dengan nilai t hitung sebesar 1,611 dan nilai signifikasi dari Pelayanan (Service) (S) $=0,115$. Sehingga, semakin baik variabel Pelayanan (Service) maka dapat meningkatkan Keberhasilan Kinerja Sistem Informasi Akuntansi Accurate Accounting Enterprise pada PT. Gunung Amal Solution International.

7. Analisis Kinerja (Performance), Informasi dan Data (Information and Data), Nilai Ekonomi (Economic), Pengendalian dan Pengamanan (Control and Security), Efektifitas (Efficiency) dan Pelayanan (Service) Memiliki Pengaruh Terhadap Keberhasilan Kinerja Sistem Informasi Akuntansi Accurate Accounting Enterprise pada PT. Gunung Amal Solution International. Dari hasil penelitian ini diketahui bahwa variabel Kinerja (Performance), Informasi dan Data (Information and Data), Nilai Ekonomi (Economic), Pengendalian dan Pengamanan (Control and Security), Efektifitas (Efficiency) dan Pelayanan (Service) secara bersamasama atau simultan itu memiliki hubungan yang signifikan terhadap Keberhasilan Kinerja Sistem Informasi Akuntansi Accurate Accounting Enterprise pada PT. Gunung Amal Solution International tingkat hubungan dengan nilai $f$ hitung 13,353 dengan nilai sig 0,000 dan nilai $R$ Square 0,631 tingkat pengaruh variabel $X$ terhadap variabel $Y$ sebesar 63\%. Sehingga semakin baik variabel Kinerja (Performance), Informasi dan Data (Information and Data), Nilai Ekonomi (Economic), Pengendalian dan Pengamanan (Control and Security), Efektifitas (Efficiency) dan Pelayanan (Service) maka dapat meningkatkan Keberhasilan Kinerja Sistem Informasi Akuntansi Accurate Accounting Enterprise pada PT. Gunung Amal Solution International.

\section{Kesimpulan}

Hasil pengujian atas model yang diajukan menunjukkan hasil yang baik. Berdasarkan penelitian yang telah dilakukan pada Kinerja Sistem Informasi Akuntansi Accurate Accounting Enterprise pada PT. Gunung Amal Solution International, maka dapat diambil kesimpulan sebagai berikut:

a. Dari hasil penelitian ini diketahui bahwa variabel Kinerja (Performance) itu memiliki hubungan negatif signifikan terhadap Keberhasilan Kinerja Sistem Informasi Akuntansi Accurate Accounting Enterprise tingkat hubungan dengan nilai t hitung sebesar $-0,828$ dan nilai signifikasi dari Kinerja (Performance) $(\mathrm{P})=0,413$.

b. Variabel Informasi dan Data (Information and Data) itu memiliki hubungan positif signifikan terhadap Keberhasilan Kinerja Sistem Informasi Akuntansi Accurate Accounting Enterprise tingkat hubungan dengan nilai $t$ hitung sebesar 6,572 dan nilai signifikasi dari Informasi dan Data (Information and Data) $(I)=0,000$.

c. Variabel Nilai Ekonomi (Economic) itu tidak memiliki hubungan negatif signifikan terhadap Keberhasilan Kinerja Sistem Informasi Akuntansi Accurate Accounting Enterprise tingkat hubungan dengan nilai t hitung sebesar $-1,437$ dan nilai signifikasi dari Nilai Ekonomi (Economic) $(\mathrm{EC})=0,159$.

d. Variabel Pengendalian dan Pengamanan (Control and Security) itu memiliki hubungan negatif signifikan terhadap Keberhasilan Kinerja Sistem Informasi Akuntansi Accurate Accounting Enterprise tingkat hubungan dengan nilai t hitung sebesar $-0,166$ dan nilai signifikasi dari Pengendalian dan Pengamanan (Control and Security) $(\mathrm{C})=0,869$.

e. Variabel Efektifitas (Efficiency) itu memiliki hubungan negatif signifikan terhadap Keberhasilan Kinerja Sistem Informasi Akuntansi Accurate Accounting Enterprise tingkat hubungan dengan nilai t hitung sebesar 1,596 dan nilai signifikasi dari Efektifitas (Efficiency) $(\mathrm{EF})=0,119$.

f. Variabel Pelayanan (Service) itu memiliki hubungan negatif signifikan terhadap Keberhasilan Kinerja Sistem Informasi Akuntansi Accurate Accounting Enterprise tingkat hubungan dengan nilai t hitung sebesar 
1,611 dan nilai signifikasi dari Pelayanan (Service) (S) =0,115.

g. Variabel Kinerja (Performance), Informasi dan Data (Information and Data), Nilai Ekonomi (Economic), Pengendalian dan Pengamanan (Control and Security), Efektifitas (Efficiency) dan Pelayanan (Service) secara bersama-sama atau simultan itu memiliki hubungan yang signifikan terhadap Keberhasilan Kinerja Sistem Informasi Akuntansi Accurate Accounting Enterprise tingkat hubungan dengan nilai f hitung 13,353 dengan niali sig 0,000 dan nilai $R$ Square 0,631 tingkat pengaruh variabel

\section{Saran}

$X$ terhadap variabel $Y$ sebesar $63 \%$.

penelitian lebih lanjut dapat mengembangkan model ini dengan sampel penelitian yang lebih luas dan tempat yang berbeda serta disesuaikan kembali dengan perkembangan teknologi. Selain itu penelitian ini dapat dianalisis dengan menggunakan metode lain seperti model TAM atau Delone And Mclean untuk mendapatkan perbandingan hasil penelitian terhadap analisis Keberhasilan Kinerja Sistem Informasi Akuntansi Accurate Accounting Enterprise di PT. Gunung Amal Solution International. Sehingga penelitian yang akan dilakukan selanjutnya dapat

\section{Referensi}

Asari, A., Toloh, B. H., \& Sangari, J. R. (2018). Pengembangan ekowisata bahari berbasis masyarakat di desa Bahoi, kecamatan Likupang Barat, kabupaten Minahasa Utara. Jurnal IImiah Platak, 6(1), 29-41.

Chalarce, T. \& Arung, G. (2019). Analisis Faktor Penerimaan Dan Penggunaan Software Accurate Dalam Perspektif Technology Acceptance Model (Studi Empiris Pada Mahasiswa Program Studi S1 Jurusan Akuntansi Fakultas Ekonomi Universitas Tadulako). Jurnal Akun Nabelo, Vol 1, No 2, hlm. 1-11.

CPSSoft. (2015). Manual Book Accurate 5. Jakarta : CPSSoft.

Hery. (2014). Akuntansi Keuangan Menengah I. Jakarta: PT Bumi Aksara.

Hudin, J. \& Riana, D. (2016). Kajian Keberhasilan Penggunaan Sistem Informasi Accurate Dengan
Menggunakan Model Kesuksesan Sistem Informasi Delon Dan Mclean. Jurnal Sistem Informasi, Vol. 1, No. 12, hlm 1-8.

Perdani, M., Dolorosa, K., \& Pulus, I. (2018). Faktor-Faktor Yang Mempengaruhi Pertumbuhan Startup di Yogyakarta. Seminar Nasional Teknologi Informasi dan Komunikasi 2018 (SENTIKA 2018), hlm. 337-349.

Samryn, L. M. (2015). Pengantar Akuntansi Buku 1 Metode Akuntansi untuk Elemen Laporan Keuangan Diperkaya dengan Perspektif IFRS \& Perbankan. Jakarta : Rajawali..

Sebrina, N. \& Taqwa, S. (2017). Pengaruh Penerapan Standar Akuntansi Keuangan (Konvergensi IFRS) Terhadap Relevansi Nilai Informasi Akuntansi. Jurnal WRA, Vol 5, No 1, hlm. 905-926.

Sitepu, S. N. Br. (2017). Pengaruh Faktor Internal Terhadap Keberhasilan Start-Up Bisnis di Kota Surabaya. Jurnal Manajemen Teori dan Terapan, Tahun 10, No. 1, hlm. 3750.

Syaradila, I. (2017). Pengaruh Teknologi Informasi, Keahlian Komputer, Formalisasi Pengembangan Sistem Informasi, dan Dukungan Manajemen Puncak Terhadap Sistem Informasi Akuntansi (Studi Empiris Pada Rumah Sakit Swasta Yang Terdaftar di Dinas Kesehatan Kota Pekanbaru). JOM Fekon,Vol. 4, No. 1, hlm. 3241-3255.

Supriyatna, A. (2017). Analisis Tingkat Kepuasan Pengguna dan Tingkat Kepentingan Penerapan Sistem Informasi DJP Online dengan Kerangka PIECES, Khazanah Informatika, Vol. III, No. 2, hlm 88 94.

Werthi, K. \& Khrisdayanti, N. (2017). Pengaruh Data Keuangan Dan Non Keuangan Pada Nilai Perusahaan (Studi Kasus Pada Startup Patriat). Jurnal Bisnis Darmajaya, Vol.3, No.1, hlm. 55-64.

Wetherbe, J., \& Vitalari, N. (2012). Systems Analysis and Design: Traditional, Best Practices. Jakarta: Ed, 4.

http://ejurnal.ars.ac.id/index.php/jti 